\title{
Identification of effective factors and components of cognitive readiness of university presidents from the perspective of cognitive science and higher education experts
}

\author{
Ali lotfi" ${ }^{1 *}$ iD, Sayed Kamal Kharazi², Javad Pour Karimi ${ }^{3}$, Mitra Ezzati ${ }^{3}$ \\ 1. PhD in Higher Education Management, Faculty of Psychology and Educational Sciences, Department of Management and Educational \\ Planning, Tehran University, Tehran, Iran \\ 2. Professor of Faculty of Psychology and Educational Sciences, Department of Management and Educational Planning, Tehran Univer- \\ sity, Tehran, Iran \\ 3. Assistant Professor of Faculty of Psychology and Educational Sciences, Department of Management and Educational Planning, Tehran \\ University, Tehran, Iran
}

Recieved: 16 Jan. 2018

Revised: 21 May. 2019

Accepted: 23 May. 2019

Keywords

Cognitive readiness

Individual cognitive readiness

Team cognitive readiness

Learning readiness

Socio-emotional readiness

\section{Corresponding author}

Ali Lotfi, PhD in Higher Education Management, Faculty of Psychology and Educational Sciences, Department of Management and Educational Planning, Tehran University, Tehran, Iran

Email: Lotfi6527@gmail.com

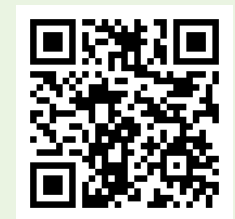

\section{Abstract}

Introduction: Cognitive readiness is one of the emerging issues in the field of cognitive science that has been raised in response to the complex condition, changing, and unpredictable at the United States Department of Defense for more than a decade. The present study aimed to investigate the cognitive readiness of university presidents due to the complexity of the university environment and the unpredictability of its events and developments.

Methods: To do the research, the meta-synthesis qualitative research method based on seven stages of Sandelowski and Barroso (2007) was used to design a tentative model to measure the cognitive readiness of university presidents through the interview with cognitive science and higher education management experts for pattern validation.

Results: The results of the research consisted of effective factors (including environmental and organizational factors) on cognitive readiness of university presidents, and the components of their cognitive readiness including individual cognitive readiness (meta-cognition, critical-analytical thinking, creative thinking, systematic thinking, situation awareness, sensemaking, adaptability), team cognitive readiness (cognitive ability and work-team interactions), learning readiness (learning mental agility), and socio-emotional readiness (social-emotional intelligence, stress management), which presented and validated as a conceptual model, and the relialibility of the model measured.

Conclusion: Cognitive readiness is a complex and multidimensional structure acquired as the result of interaction between environmental, organizational factors and its components, which would have major impacts on the success of university presidents, accordingly.

\footnotetext{
Citation: Lotfi A, Kharazi S K, Pour Karimi J, Ezzati M. Identification of effective factors and components of cognitive readiness of university presidents from the perspective of cognitive science and higher education experts. Advances in Cognitive Sciences. 2019;21(3):94-104.
} 
D)

\title{
شناسايى عوامل مؤثر و مؤلفه هاى آمادتى شناختى رؤساى دانشكاه از نظر متخصصان علوم شناختى و آموزش عالى
}

\author{
على لطفى" (1) ، سيدكمال خرازى"، جواد يوركريمى"، ميترا عزتى"
}

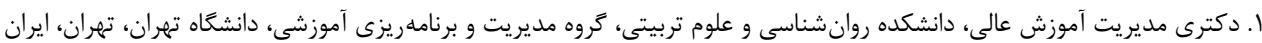

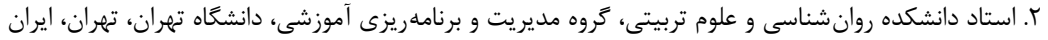

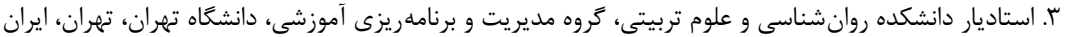

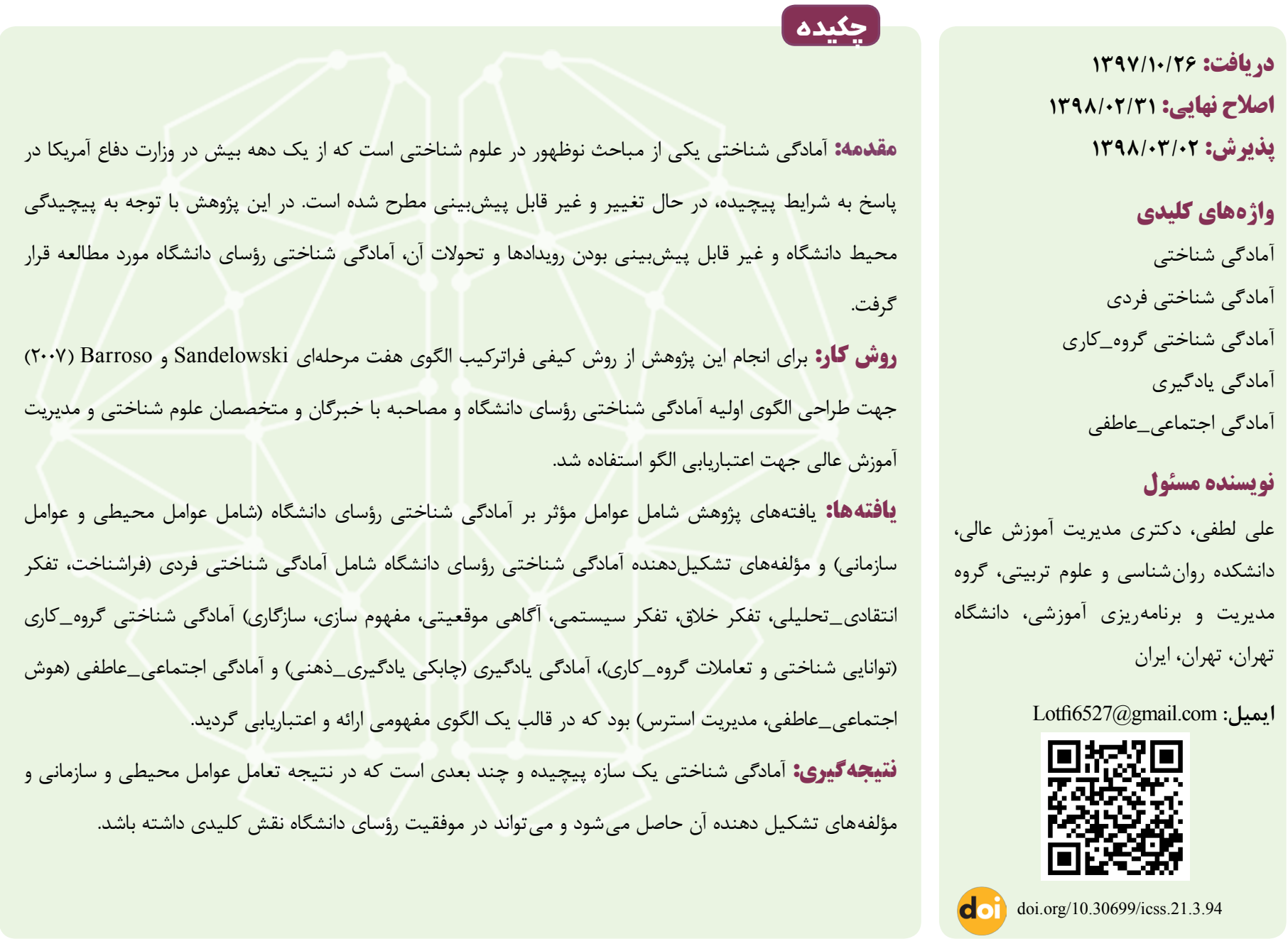

مقدمه

آموزش عالى درصدد بهبود مستمر عملكرد رؤساى خود باشند. اگر رؤساى دانشخاهها و مؤسسات آموزش عالى از توانايى لازم در محيط در حال تغيير و يوياى دانشخاه برخوردار باشند، مىتوان كفت كه دانشخاهها در رسيدن به اهداف و مأموريتهاى خود موفق خواهند بود (1). از سوى ديخر شرايط اجتماعى، فرهنگى، سياسى و اقتصادى دانشخاهها
مديريت و رهبرى در دانشعاهها و مؤسسات آموزش عالى به دليل تغيير و تحولاتى كه در عصر حاضر در حال وقوع است، اهميت ويزهاى يافته است. عواملى جون ورود فناورىهاى نوين اطلاعاتى و ارتباطى، مديريت و توليد دانش، بين المللى شدن آموزش عالى، رقابت مؤسسات آموزش عالى و تحولات اجتماعى موجب شده است كه دانشخاهها و مؤسسات 
افزايش رقابت جهانى، ظهور فناورىهاى جديد، جهانىشدن، بازارهاى نوظهور و ظهور اقتصاد دانشبنيان لازم است كه مديران دانشعاه از آمادكى لازم براى فعاليت در جنين محيطى آمادكى داشته باشند.

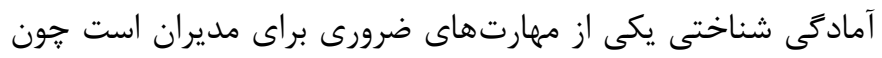

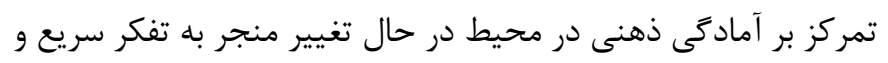

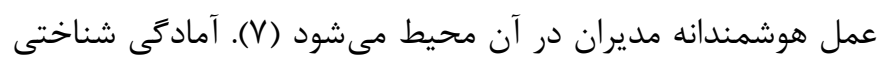

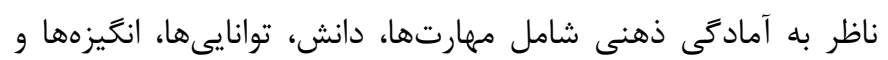

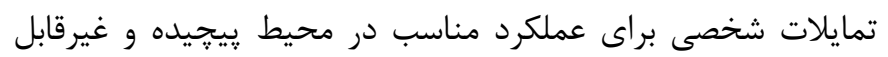

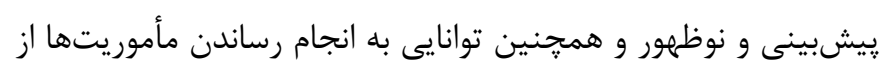
طريق تصميم كيرى و اجراى تصميم به شيوه كار آمد و بهروز در محيط در حال تغيير و يِيجيده است (^).

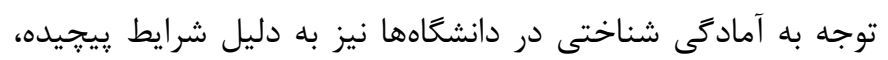

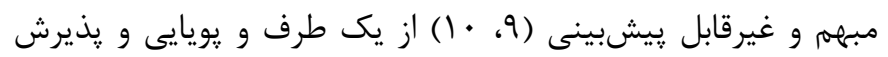

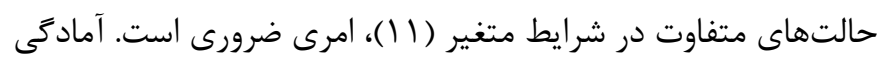

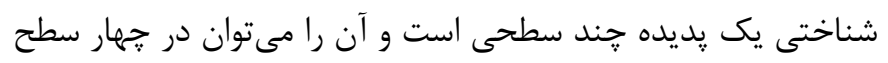

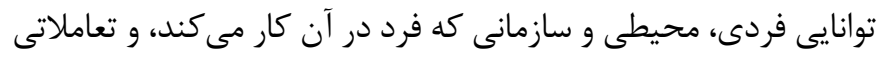

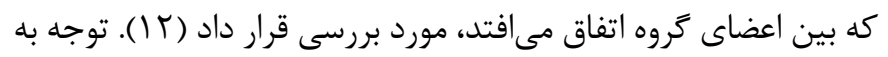

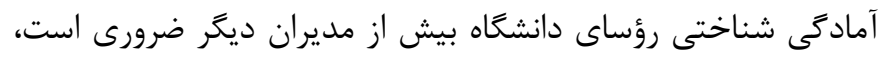

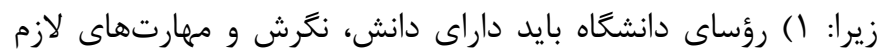

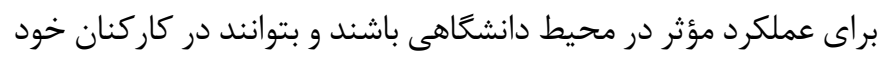

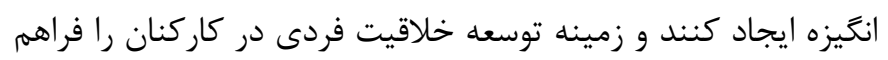

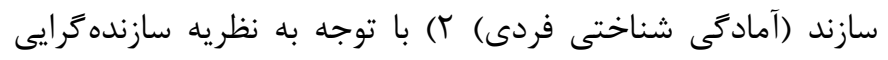

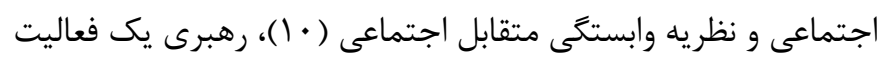

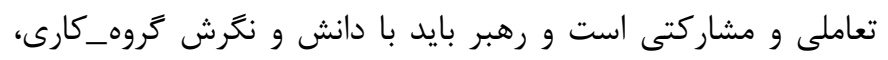

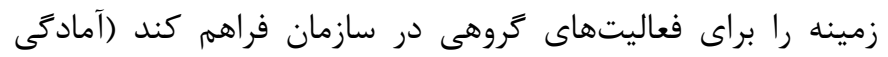

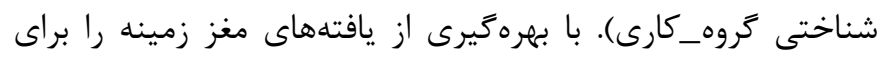
تعاملات و فعاليتهاى مشاركتى در محيط دانشخاه فراهم آورد (ب ا).

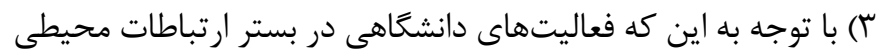

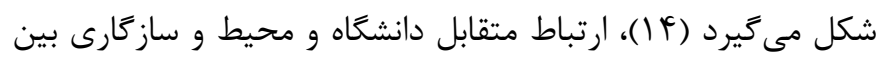

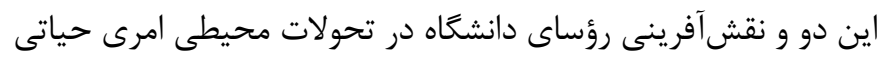
است (آمادگى شناختى محيطى).

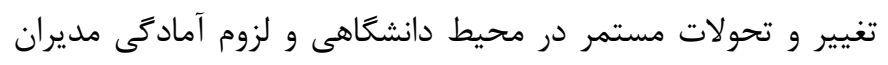

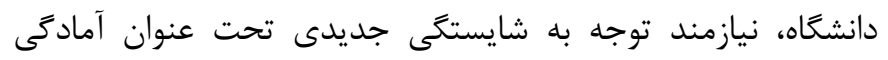

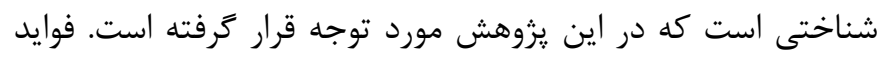

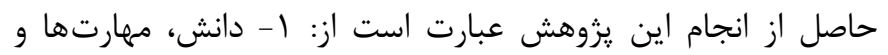
توانايىهايى لازم را براى فعاليت مديران در محيط در حال تغيير را مشخص مى كند. r- به افزايش مهارتهاى نرم در مديران مانند
و مؤسسات آموزش عالى ايجاب مى كند به كونهاى برنامهريزى كنند كه بتوانند در شرايط در حال تغيير، به فعاليت خود ادامه دهند. براى

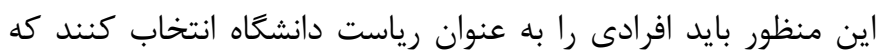

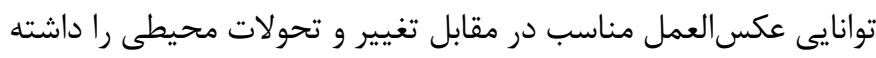

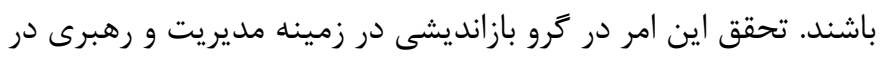

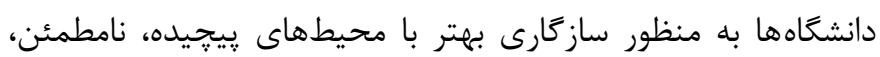

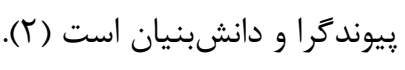

يكى از محورهاى مههم بازانديشى در حوزه مديريت و رهبرى سازمانها توجه به آموزههاى علوم شناختى است كه در حال حاضر به عنوان يك رويكرد نوين در سازمانها مورد توجه قرار كرفته است. رويكرد شناختى به مديريت با تمركز بر فرايندهاى فكرى و مدلهاى ذهنى

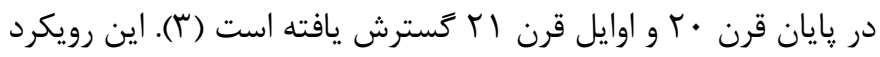
منجر به شكل گيرى رويكرد نوينى تحت عنوان ابعاد شناختى سازمان و مديريت شده Managerial and organizational cognition) كه نقش ديدَاهها و تجربيات مديران رادر شكل گيرى (perspective

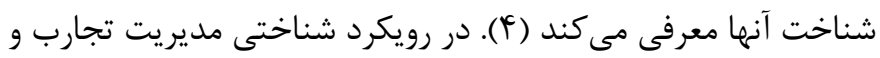

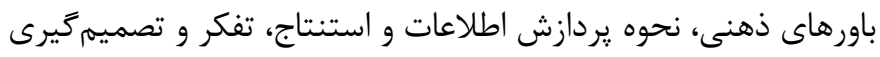

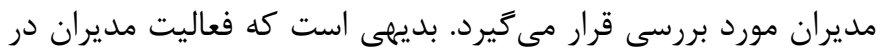

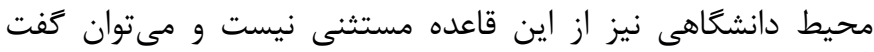

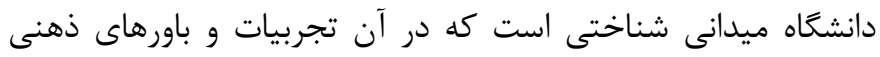

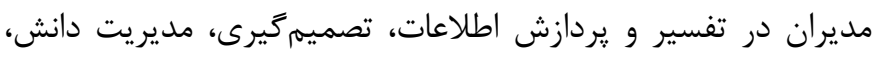

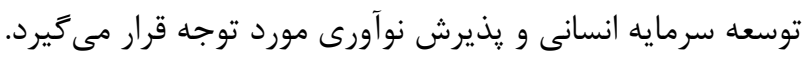
توجه به شناخت به توسعه قابليتهاى اساسى كمك مى كند و و يايهاي

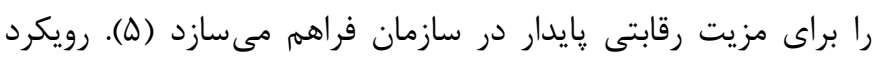

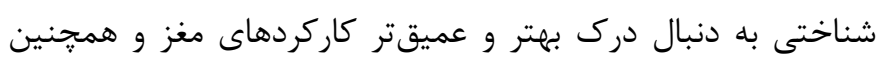
درى و فهم بهتر فعاليتهاى انسانى در عرصه مديريت و رهبرى است. متخصصان علوم سازمانى با بهرهيرى از كاركرد مغز سعى مي كنند كه سازمان را (به مثابه مغز) به كونهاى طراحى كنند كه انعطاف

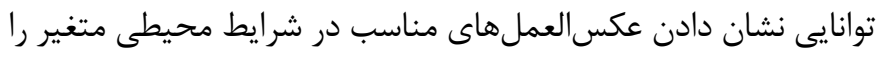

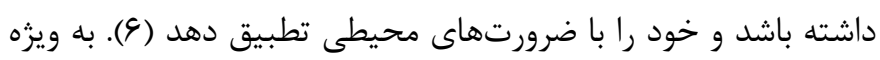

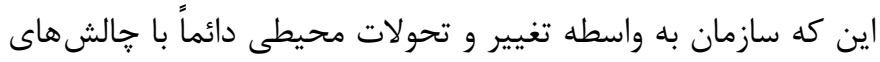
جديدى روبرو است. در جنين شرايطى يكى از مهمترين فعاليتهاى رؤساى دانشعاه توجه

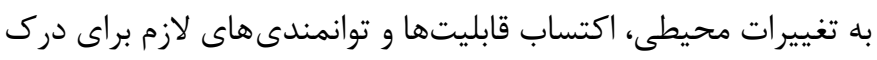
و شناخت تغييرات، مواجهه با آنها، انعطافيذيرى در راسخكويى به

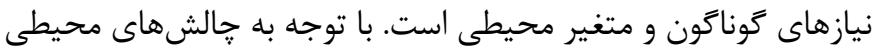

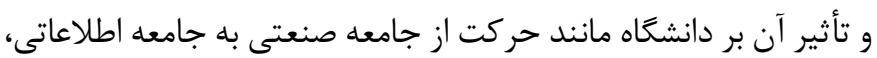


و Sandelowski تحقيق r. مطالعه نظاممند ادبيات يزوهش r. جستجو و انتخاب

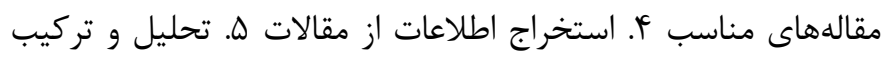

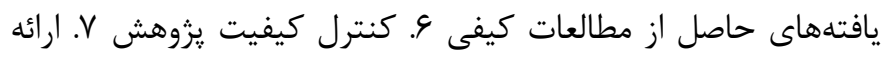

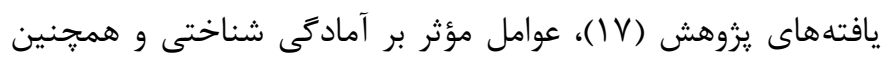

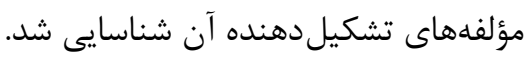

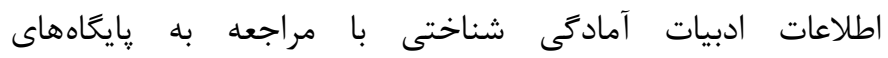
و Google scholar و ScienceDirect, ISC, Scopus, Irandoc استفاده از كليد وازههايى مانند آمادكى شناختى، آمادكى شناختى فردى، آمادگى شناختى كروه_كارى، آمادگى شناختى محيطى، توانايى شناخت كروه_كارى، توانايى شناخت محيطى، شناخت و ادراك محيطى، مؤلفهاى شناخت سازمانى و فرايندهاى شناخت فردى

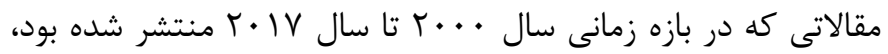

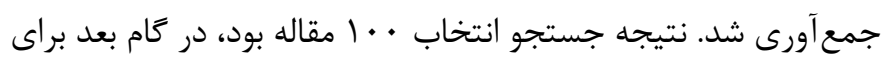

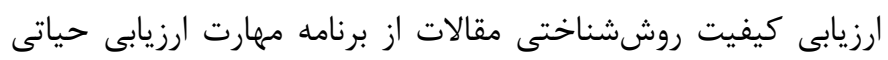
(Critical Appraisal Skills Program (CASP)) اساس اين ارزيابى، • f مقاله براى بررسى انتخاب گرديد. براى اطمينان از ارزيابى مقالات از روش فهرست وارسى توسط مشاركتكنندكان

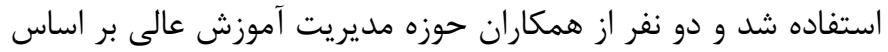
سياهه CASP مقالات منتخب را مورد ارزيابى قرار دادند. سيس نتايج حاصل از طريق ضريب توافق كدَذاران با استفاده از شاخص كايا و با

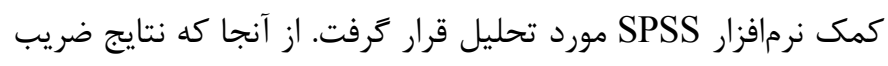
كايا بالاتر از ع/• بود، ضريب توافق در سطح مناسب و مقالات استخراج شده قابل قبول تلقى شد. مرحله دوم) بعد از انتخاب مقالات، براى كدكذارى آنها از بـ مرحله

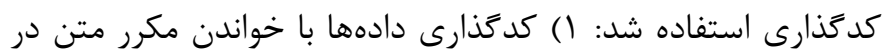
داخل خطوط و ياراكراف و يافتن يك درك كلى. محقق پس از مطالعه هر مقاله، شروع به استخراج كدها از متن مقاله كرد. در اين مرحله كدَّارى بدون هيجَّنه محدوديتى از لحاظ تعداد كدها صورت كرفت r T) به محض اين كه كدها مشخص شدند، يزوهشكر كدهاى مشابه را در قالب مفاهيم دستهبندى و در نتيجه مفاهيم يزوهش مشخص شد. r) در كام بعدى كد كذارى بر روى مفاهيم صورت كرفت.

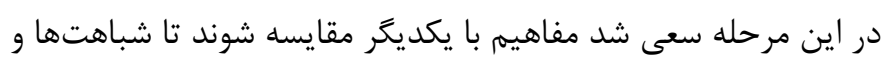
تفاوتهايشان مشخص گردد و زمينه براى شكل گيرى مقولهها فراهم

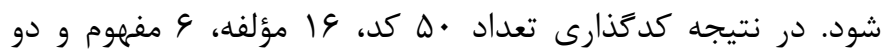
مقوله شناسايى شدند. بدين ترتيب، زمينه براى طراحى الكَىى اوليه

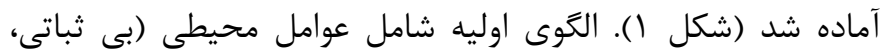

مهارتهاى ميان فردى و ارتباطى، تعامل و همكارى، كار گروهى، انعطافيذيرى، فراشناخت و... كمك مى كند. ب- از آنجايى كه در دانشخاه فعاليت كروه_كارى اهميت ويزهاى دارد، زيرا آمادكى شناختى

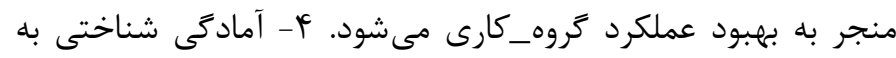

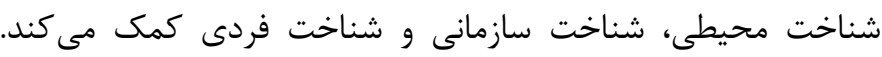

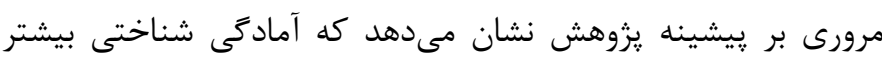
در محيطهاى نظامى بررسى شده است (ها ). اما دانشعاه و مؤسسات آموزش عالى به دليل قرار كرفتن در معرض تغيير و نوآورى مستمر، ييجيدگى موجود در دانشاه، وجود ارتباط متقابل دانشخاه و محيط، جارى و سارى بودن اطلاعات در دانشخاه و... يِيجيدهتر از محيط نظامى است زيرا مديران دانشعاهى بايد از دانش و مهارتهاى لازم براى هدايت

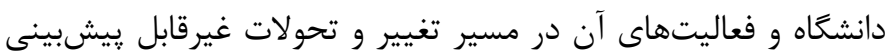
برخوردار باشند. تحقيق درباره آمادىى شناختى رؤساى دانشگاهها به دانه

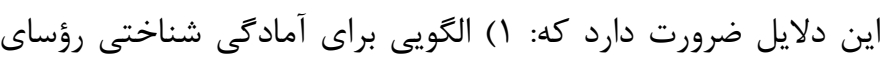
دانشغاه وجود ندارد. (Y) لازم است توسعه رويكرد شناختى به مديريت

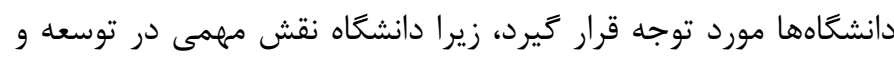
توانمندسازى سرمايه انسانى ايفا مى كند. ب) با توجه به علاقه موجود به توسعه علوم ميانرشتهاى در دانشگاهها و مؤسسات آموزش عالى، انجام تحقيقات ميان رشتهاى در باب مديريت شناختى مىتواند به گسترش

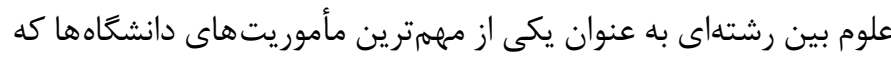

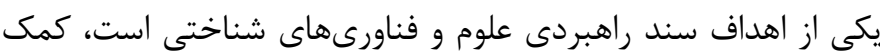

بررسى آمادگى شناختى رؤساى دانشعاهها هدف اين يزوهش بود كه در

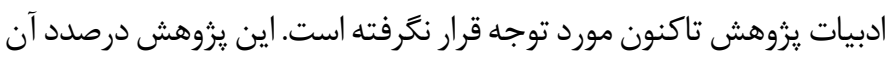
بود كه به اين سؤال ياسخ دهد كه الالخوى آمادگى شناختى رؤساى دانشخاه جيست؟). براى رسيدن به اين هدف \& سؤال زير مطرح شد: () عوامل مؤثر بر آمادگى شناختى رؤساى دانشكاه كدامند؟ ؟) مؤلفههاى تشكيلدهنده

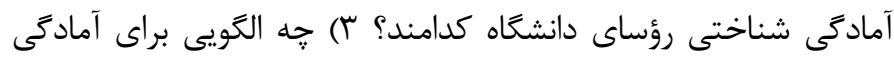

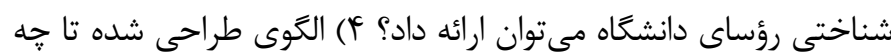

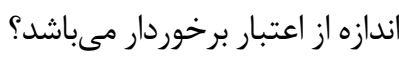

\section{روش كار}

اين يزوهش در دو مرحله انجام شد: مرحله اول) بررسى ادبيات يزوهش:

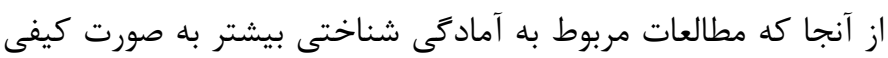
و بدون دادههاى كمى بود، از روش فراتركيب براى به دست آوردن تركيب جامعى از مؤلفههاى آمادكى شناختى استفاده شد. همجنين

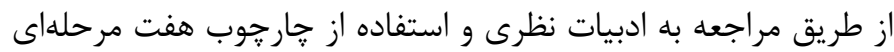


(آمادگى شناختى فردى، آمادگى شناختى گروه_كارى، آمادگى يادگيرى و آمادگى اجتماعى_عاطفى) بود.

يِيجيدگى، عدم قطعيت و ابهام محيطى)، عوامل سازمانى (مديريت دانش، يويايى اطلاعات و فرهنگ سازمانى) و مولفه هاى تشكيل دهنده

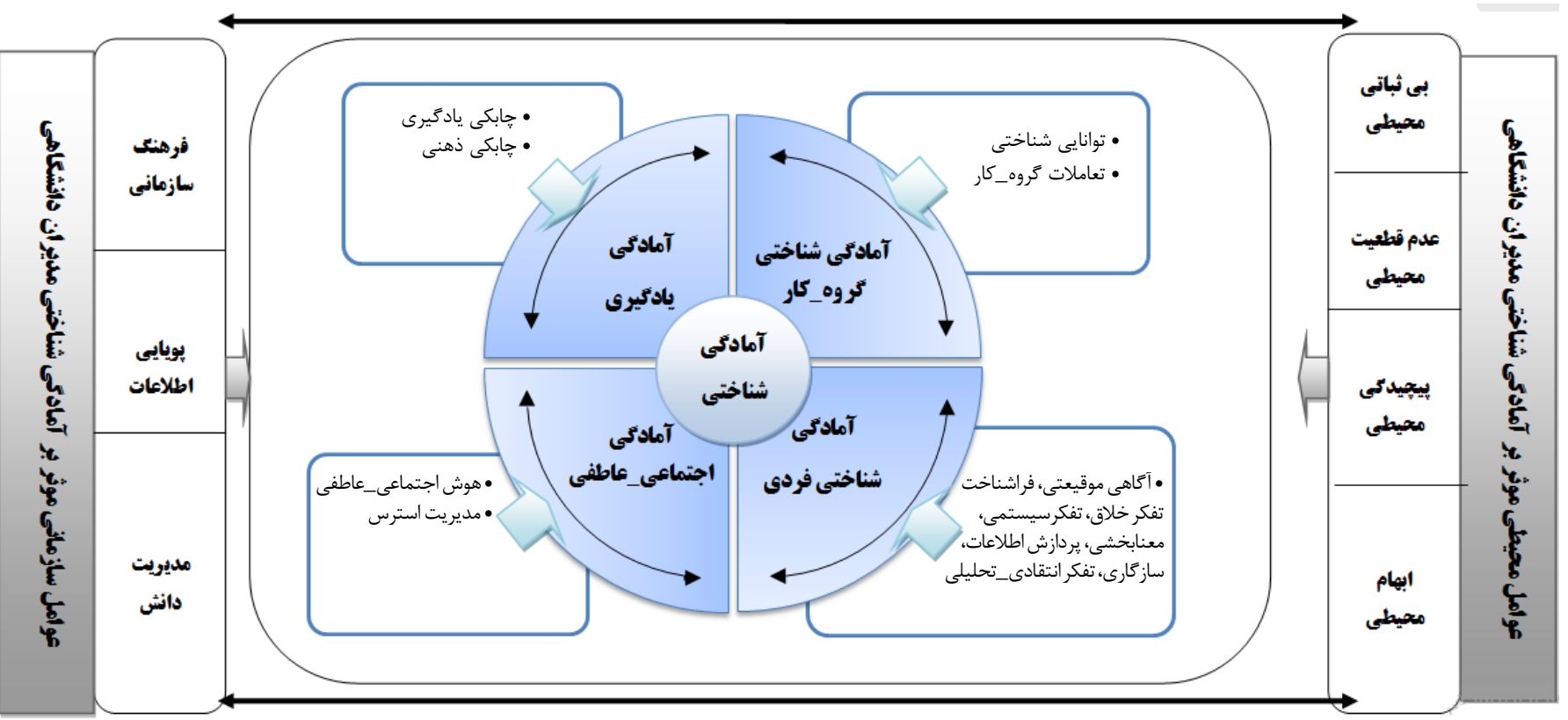

شكل ا. الكَوى اوليه آمادگى شناختى رؤساى دانشحاه استخراج شده با فراتركيب

را صحبتهاى مصاحبهشوندگان براى آنها بيان كند. در فرايند مصاحبه آر نياز به توضيح و تبيين بيشترى درباره مؤلفهها و زير مؤلفههاى آمادگى شناختى مديران دانشگاه از طرف مصاحبه كننده بود و يا اخر ابهامى در بخشى از مطالب وجود داشت، با همكارى مصاحبهشونده انجام مىشد. مصاحبه كننده در يايان مصاحبه نظر مصاحبهشوند درباره جمعبندى خود از مباحث مطرح شده را جويا مىشد. براى ايجاد اطمينان، يادداشتبردارى در تمام مراحل مصاحبه صورت گرفت و تمام تلاش گروهشگر بر اين بود كه جارجوب موضوعى رعايت شود. نتايج حاصل از مصاحبه بلافاصله در اختيار استاد محترم راهنما قرار زرفت و ايشان نظر خود را بيان كرد. صاحبنظران و خبركان ضمن تأييد كليت كار و تحليلهاى صورت گرفته در بخش كيفى يزوهش نقطه نظرات اصلاحى را مطرح نمودند. عمدهترين اصلاحاتى كه در نتيجه انجام مصاحبه انجام شد، عبارت بود از: () بازنگرى متن گزارش و اصلاح نواقصى كه متخصصان و خبركان مطرح كردند. r) توجه به ارتباط متقابل بين مؤلفههاى جهار گانه آمادگى شناختى مديران دانشخاهى. ץ) اصلاح نامحذارىهاى انجامشده براى مؤلفه و زير مؤلفهها. براى مثال ابهام محيطى و عدم قطعيت محيطى به لحاظ هميوشى در يك مولفه تحت عنوان ابهام و عدم قطعيت محيطى آمده است. يا دو مولفه توانايى
״س از طراحى الكوى اوليه آمادگى شناختى رؤساى دانشگاهها، از روش مصاحبه ساختاريافته براى اعتباريابى الگو استفاده گرديد. براى اين كار يرسشنامهاى شامل مقدمه، عوامل مؤثر بر آمادگى شناختى مديران و مؤلفههاى تشكيلدهنده آمادكى شناختى مديران طراحى شد، بدون اين كه الكوى اوليه طراحى شده در اختيار آنها قرار داده شود. با روش نمونه گيرى كلوله برفى از ميان متخصصان و صاحبنظران حوزه علوم شناختى و مديريت آموزش عالى كه آشنايى نسبى درباره موضوع مورد مطالعه داشتند، به عنوان مصاحبه شونده انتخاب شدند. مصاحبه شوند نظرات خود را درباره مولفههاى و زير مولفههاى آمادگى شناختى رؤساى دانشعاه ها مطرح كردند. فرايند مصاحبه در يك بازه زمانى جهار ماهد از

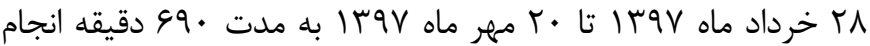
شده است. از ال نفر از متخصصان حوزه مديريت آموزش عالى و 9 نفر از متخصصان حوزه علوم شناختى مصاحبه به عمل آمد. البته تعداد مصاحبهها از قبل مشخص نبود، بلكه فرايند انجام مصاحبه تا رسيدن به حالت اشباع نظرى ادامه يِيدا كرد. منظور از اشباع حالتى است كه

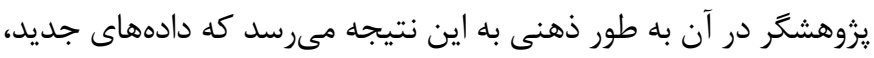
اطلاعات جديد يا شناخت بيشترى به دست نمى دهند (1) ). در فرايند مصاحبه سعى شد سؤالات به صورت شفاف و به دور از هر گونه ابهام با مصاحبهشوندگًان در ميان كذاشته شود. مصاحبه كننده سعى كرد صحبتهاى مصاحبهشوندكان را به صورت فعال بشنود و درى خود 
در سه حوزه مديريت دانش، يويايى اطلاعات و فرهنت سازمانى مورد بررسى قرار گرفت. اما در فرايند مصاحبه خبر گان و متخصصان به اين نكته اشاره كردند كه مديريت دانش و يويايى اطلاعات را مىتوان در فرايند سازمانى مورد بررسى قرار داد. يكى ديگر از نكاتى كه مصاحبه

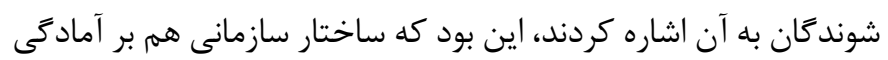
شناختى رؤساى دانشعاه ها تأثير كذار است. در نهايت بر اساس نظرات

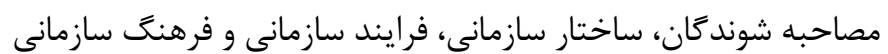
به عنوان عوامل سازمانى موثر بر آمادگى شناختى مديران دانشعاهى مطرح شد. با توجه به موارد مطرح شده، الگوى آمادگى شناختى رؤساى
شناختى گروه كار و تعاملات گروه كار در يك مولفه تحت عنوان توانايى شناختى و تعاملات گروه_كار آمده است. (F) جابكى يادگيرى و جابكى ذهنى به لحاظ شباهت در كدها، تحت عنوان خابكى يادگيرى_ذهنى آمده است. ه) عوامل محيطى و عوامل سازمانى در يك سطح نيستند، عوامل محيطى بالاتر از عوامل سازمانى قرار گيرد. ؟) يكى از مهرمترين تغييرات انجام شده يس از فرايند مصاحبه، اصلاح عوامل سازمانى موثر بر آمادگى شناختى مديران دانشگاهى بود. در الخوى اوليه عوامل سازمانى موثر بر آمادگى شناختى رؤساى دانشعاهها

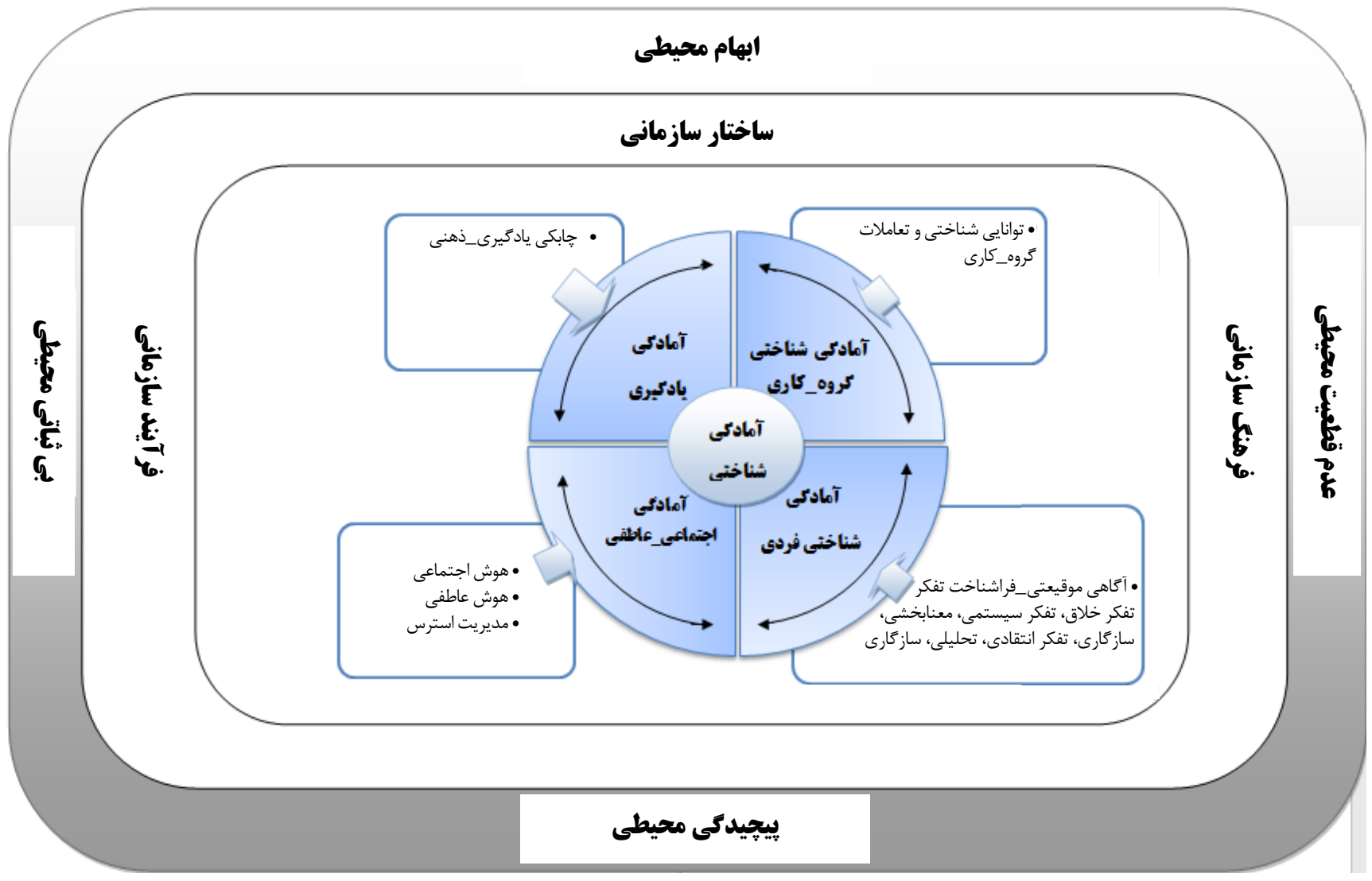

شكل r. الكوى اوليه آمادگى شناختى رؤساى دانشعاه برآمده از نظر متخصصان

شناختى ارائه دهند. با توجه به ماهيت ميان رشتهاى بودن آمادگى شناختى (علوم شناختى و مديريت آموزش عالى) از نظرات متخصصان هر دو حوزه استفاده شد. آنها ضمن تأييد مولفهها و زير مولفه مهاى آمادگى شناختى، نقطه نظرات اصلاحى خود را مطرح كردند كه در طراحى الكو مورد توجه قرار گرفت. ץ) التوى دومى از جامعيت بيشترى برخوردار است، از اين جهت كه سه مولفه ساختار سازمانى (وجود و شكل گيرى ارتباطات شبكةاى، جابكى لازم براى ياسخگويى به تحولات محيطى و انعطاف يذيرى و نوآورى سازمانى)، فرايند سازمانى (توليد و به اشتراك گذارى دانش در سازمان،
دانشگاه بر آمده از نظرات متخصصان در سه لايه عوامل محيطى، عوامل سازمانى و مولفه هاى تشكيل دهنده طراحى شد (شكل r). با مقايسه الكوى برآمده از روش فراتركيب و برآمده از نظرات متخصصان مى توان به اين نكته اشاره كرد كه: () براى تدوين الكوى اوليه آمادگى شناختى از زيشينه و مبانى نظرى يروهش (تعاريف آمادگى شناختى، تبيين عوامل موثر بر آن و همجنين مولفههاى آن، الكوهاى آمادكى شناختى و ريشينه يزوهش) استفاده شد. بعد از طراحى الكوى اوليه در اختيار متخصصان و خبر گان قرار داد شد تا بتوانند نظرات خود را درباره مولفها و زير مولفههاى آمادكى 
قرار كَرفته است كه در الكَوهاى يِيشين مورد توجه قرار نكرفته است. ؟) در اين الكو آمادگى شناختى رؤساى دانشكاه در سه حوزه شناخت

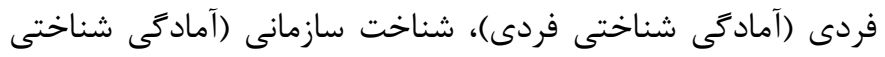
سازمانى) و شناخت محيطى (آمادگى شناختى محيطى) مورد توجه

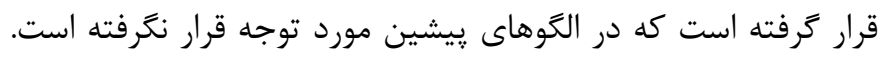

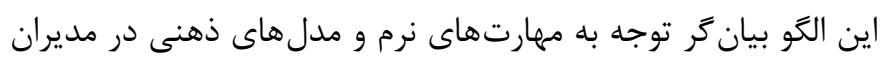
دانشخاه است و لازم است كه سرمايه كذارى در مدل هاى ذان ذهنى مدير مدان دانشكاه مورد توجه قرار گيرد. الكَى نهايى آمادگى شناختى در شكل
كاربرد و انتقال دانش در سازمان، توانايى جستوجو و فهم اطلاعات و توانايى تفسير اطلاعات) و فرهنگ سازمانى را مورد توجه قرار داده است. r) در ادبيات يزوهش آمادگى شناختى به عنوان يك يديده קند

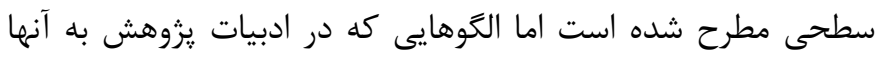

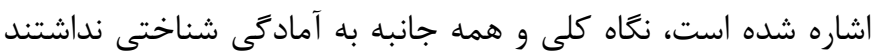

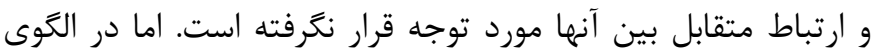
طراحى شده ارتباط متقابل مولفهها مورد توجه قرار كرفته است. نكته ديخرى كه بايد درباره الكوى طراحى شده اشاره كرد اين است كه در اين الكَ عوامل موثر بر آمادگى شناختى رؤساى دانشگاه مورد توجه

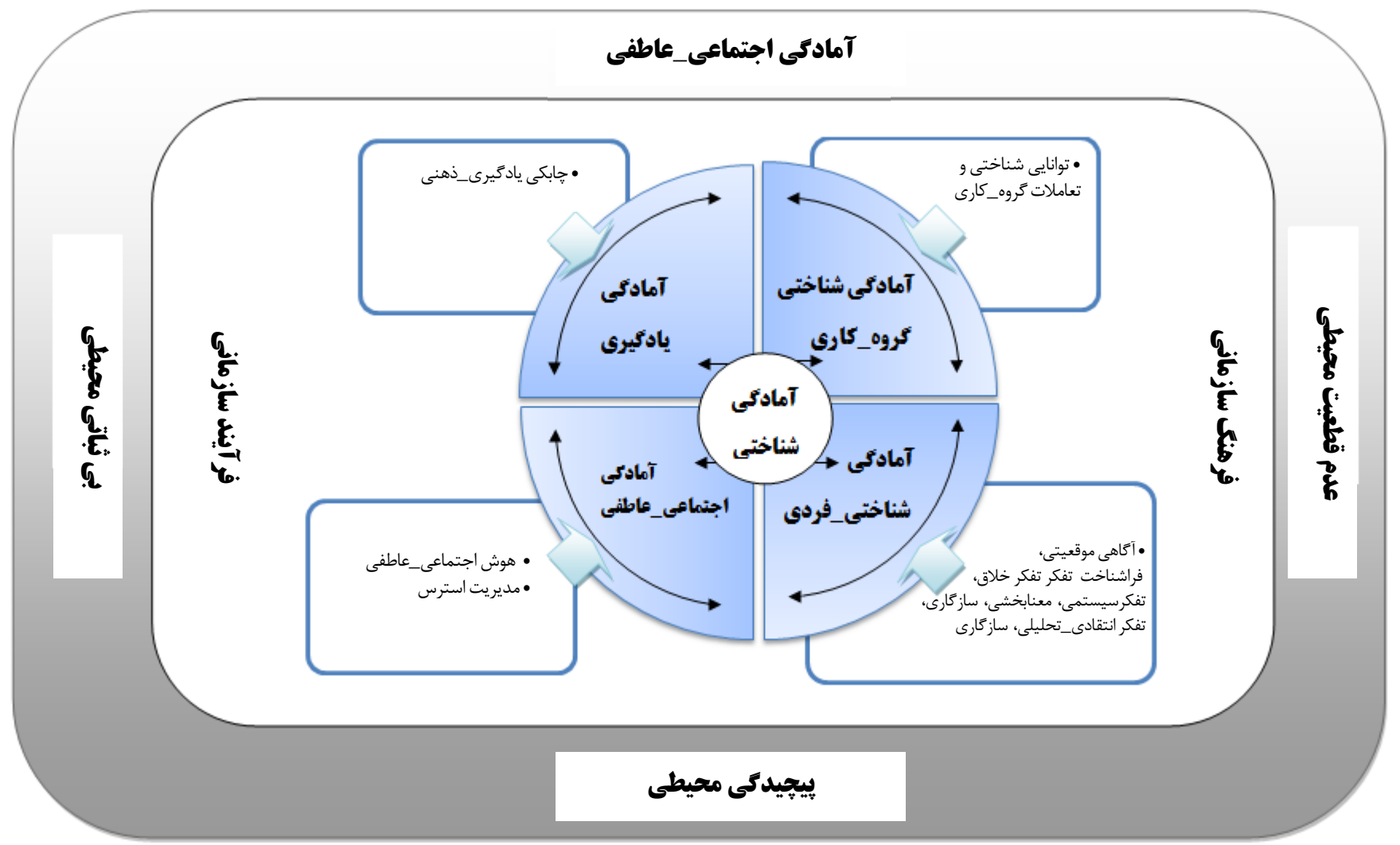

شكل r. الكوى نهايى آمادگى شناختى رؤساى دانشعاه

بافته ها

محيطى (سرعت و يويايى تغييرات محيطى و تأثير آن بر فعاليتهاى دانشگاه) و ييجيد

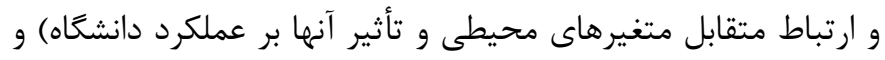
عامل سازمانى (شامل ساختار، فرهنَ و فرايند سازمانى) بر آمادگى

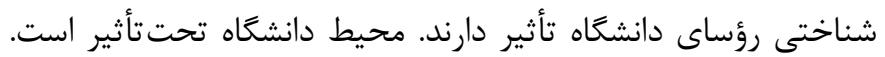
در جنين شرايطى آن خه مههم است واكنش سريع، به موقع و درست

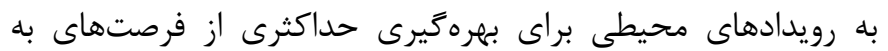

يافته هاى يزوهش در دو بخش عوامل موثر بر آمادكى شناختى رؤساى دانشگاه و همجنين مولفه هاى تشكيل دهنده آن توضيح داده مى دُش دود.

() عوامل موثر بر آمادكى شناختى رؤساى دانشگاه يافتههاى يزوهش نشان داد كه دو عامل محيطى شامل ابهام و عدم قطعيت محيطى (كامل نبودن اطلاعات به دليل يويايى محيط و سر و كار

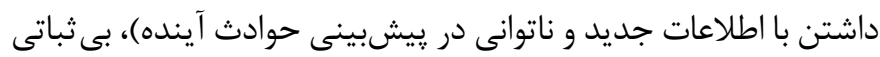


كمك مى كند براى فعاليت در محيط غيرقابلييشبينى و يِيجيده عملكرد خوبى از خود نشان دهند و بتوانند خود را با موقعيتهاى جديد انطباق دهند؛ بنابراين يكى از مهمترين ابزارها براى همسويى سازمان

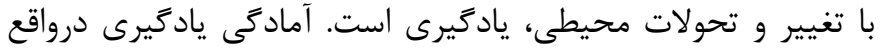

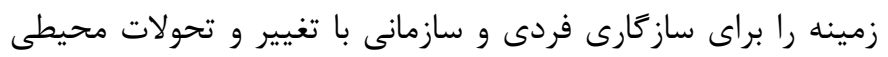

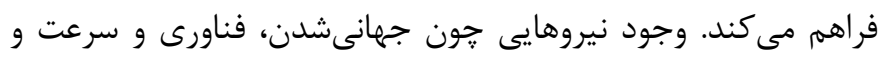

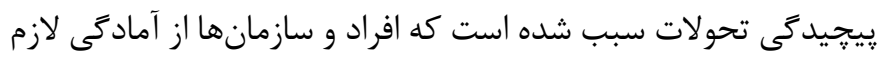

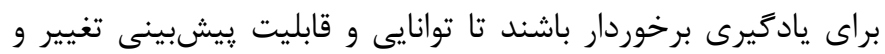

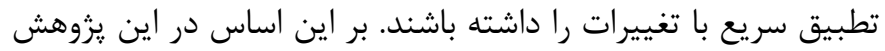

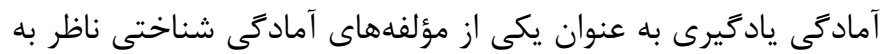
جابكى يادگيرى_ذهنى مديران دانشعاه است.

\section{د) آمادكى اجتماعى_عاطفى}

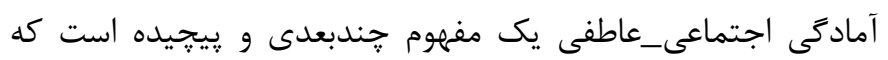

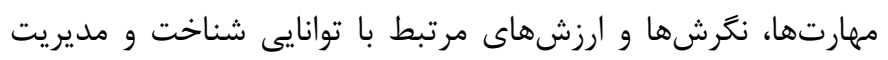
عواطف و احساسات، درك ديدكاههاى ديخران، تدوين اهداف مثبت اجتماعى و حل مسئله را در بر مى گيرد. در آمادگى شناختى فرايندهاى داى داني اجتماعى و بين فردى مورد توجه قرار كرفته است. در اين يزوهش آمادگى اجتماعى_عاطفى به عنوان يكى از مؤلفههاى آمادگى شناختى

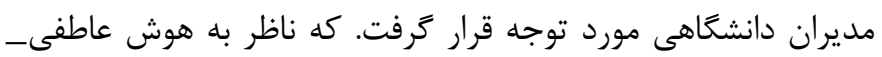
اجتماعى و مديريت استرس است.

ب) توجه به آمادكى شناختى مىتواند ياسخ مناسبى براى رويارويى با

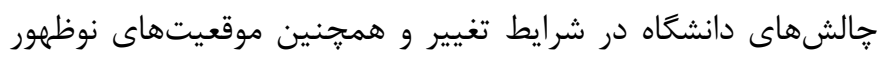
و غير قابل بيشبينى در محيط دانشخاهى در قرن الب باشد. در اين يزوهش آمادگى شناختى رؤساى دانشگاه در سه حوزه شناخت محيطى، شناخت سازمانى و شناخت فردى موردتوجه قراركرفته است. با توجه به نتيجه اين يزوهش توجه به موارد زير در آمادكى

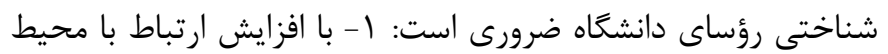

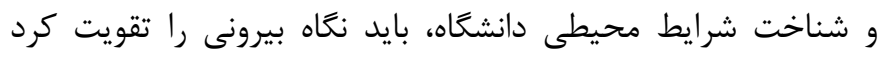

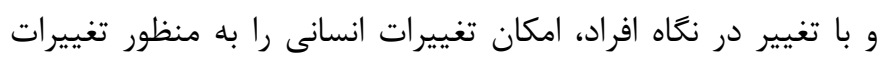

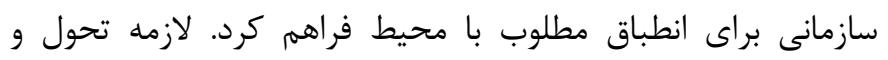
توسعه سازمان شناخت واقعى از حوادث و رويدادهاى محيطى است

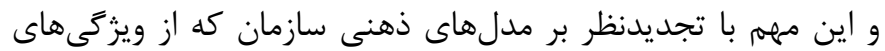
سازمان يادگيرنده است، ميسر مىشود. بر اين اساس رؤساى دانشكاه بايد تحولات محيطى را رصد كرده، بر اساس دريافتهاى خود نسبت
وجود آمده است. بر اين اساس رؤساى دانشكاه بايد تحولات محيطى را رصد كرده، بر اساس دريافتهاى خود نسبت به طراحى ساختارها و فرايندهاى دانشغاه اقدام كنند.

r (r) مؤلفههاى تشكيل دهنده آمادگى شناختى رؤساى دانشعَاه

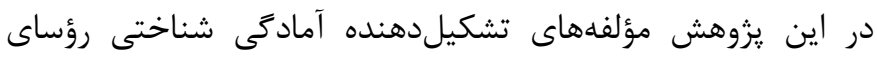

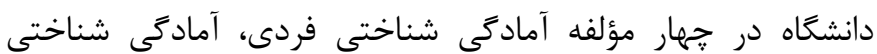
كروه_كارى، آمادگى يادگيرى و آمادگى اجتماعى_عاطفى دستهبندى

شدند.

الف) آمادكى شناختى فردى ناظر بر توانايى فردى رؤساى دانشخاه است. آمادگى شناختى فردى فردى

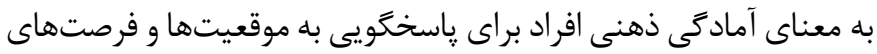
ييشرو و نوظهور است. اين نوع آمادگى متأثر از ساختارهاى ذهنى دهنى

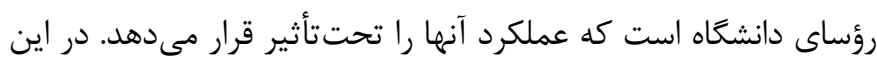
يزوهش آمادَى شناختى فردى در V مفهوم آكاهى موقعيتى، فراشناخت، خلاقيت و تفكر خلاق، سازگًارى، تفكر سيستمى، تفكر انتقادى_تحليلى و معنابخشى مورد بررسى قرار كرفت.

ب) آمادكى شناختى كروه_كارى

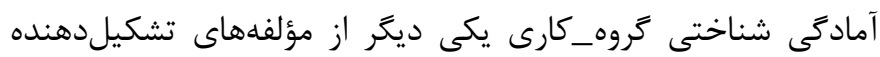

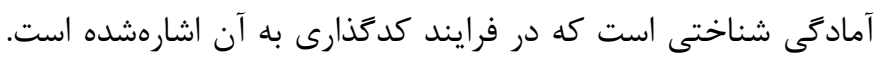

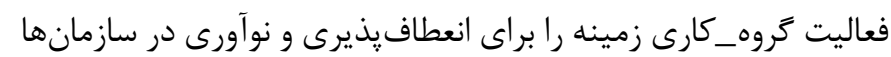

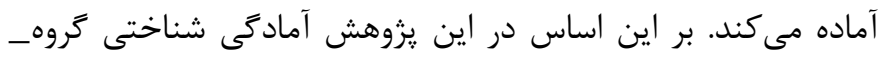

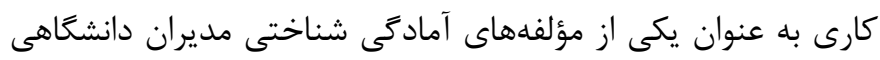

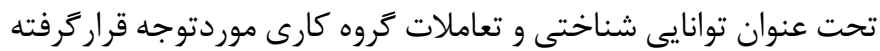
است. در آمادگى شناختى گروه_كارى فرايندهاى ذهنى دركير در تعاملات اجتماعى مورد توجه قرار مى گيرند. براى مثال نكرش مديران

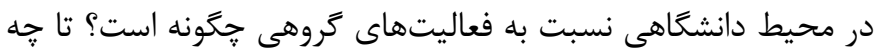

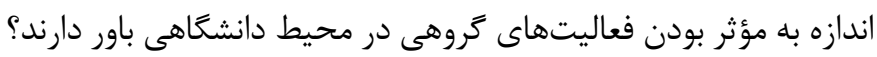
الكوهاى ذهنى مديران و كاركنان نسبت به فعاليتهاى كَروهى جَّونه

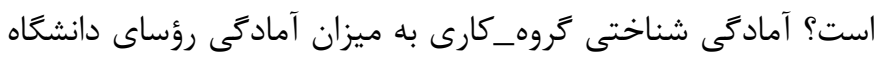

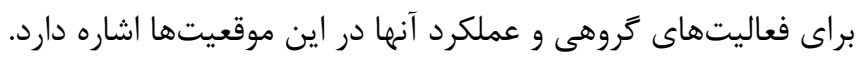

ج) (آمادگى يادگيرى آمادگى يادگيرى يكى ديخر از مؤلفههاى تشكيلدهنده آمادكى شناختى مديران دانشخاهى است. اين مهارت به مديران دانشخاهى آنى إنى 
نوين و شايسته در دستان مديران براى هدايت افراد درون سازمان و

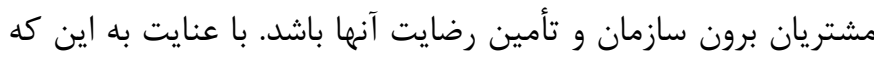

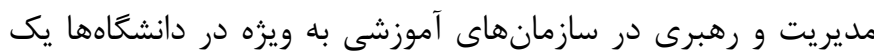

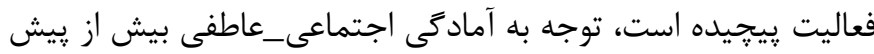

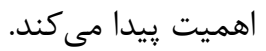
بين هركدام از جهار مؤلفه مزبور ارتباط متقابل وجود دارد، به طورى

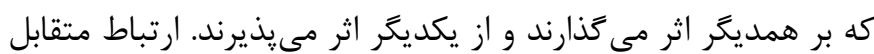
آمادگى شناختى فردى و آمادگى شناختى كروه_كارى در ادبيات

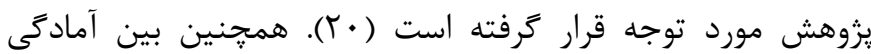
يادكيرى و آمادكى اجتماعى_عاطفى ارتباط متقابل وجود دارد (آل). بر اساس نظريه انسجام شناخت، يادكيرى يك فرايند وابسته به هيجان

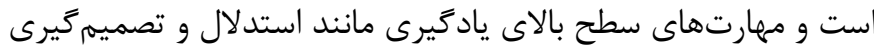

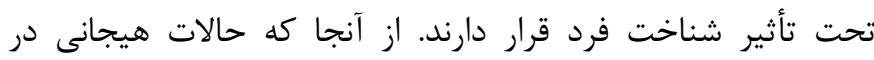

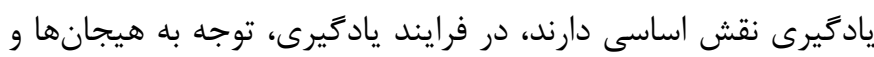

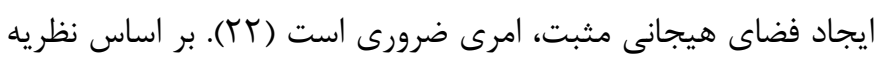
يادكيرى اجتماعى، يادكيرى يك فرايند اجتماعى است و تحت تأثير

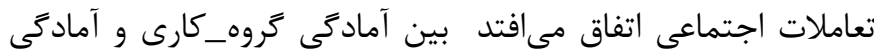
اجتماعى_عاطفى ارتباط متقابل وجود دارد. عملكرد گروه_كارى نيز تحت تأثير هوش اجتماعى_عاطفى است (T) (T).

\section{نتيجه كيرى}

در اين يزوهش آمادگى شناختى رؤساى دانشعاه مورد مطالعه قرار

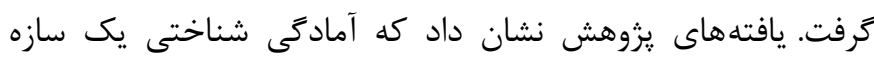

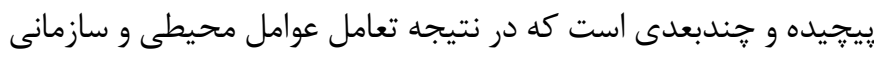
با مؤلفههاى تشكيلدهنده آمادگى شناختى حاصل مىشود. بنابراين توجه به آمادگى شناختى مىتواند به روساى دانشگاه براى اتخاذ تصميمات موثر و كارآمد كمك كند و اين امر بايد مورد توجه قرار گيرد.

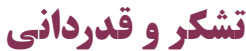

اين مقاله استخراج شده از بخش كيفى رساله دكترى مديريت آموزش عالى دانشعاه تهران تحت عنوان طراحى الكوى آمادكى شناختى مديران

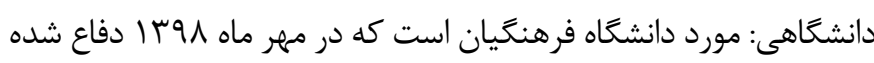
است و با كد 99. هو در كتابخانه مركزى دانشكاه تهران ثبت شده است.
به طراحى ساختارها و فرايندهاى دانشگاه اقدام كنند. ويزگى هاى جهار كانه محيطى جالشهايى را براى سازمان ايجاد كرده است. انتظار

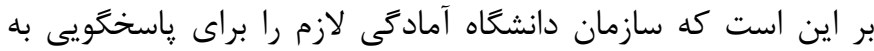

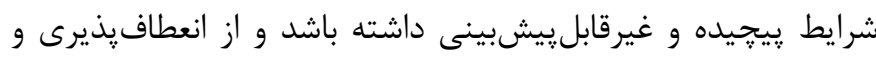

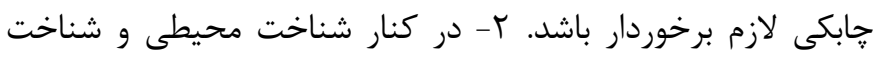

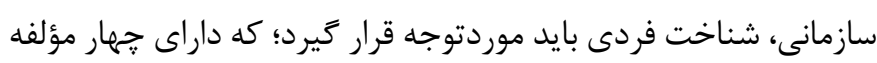

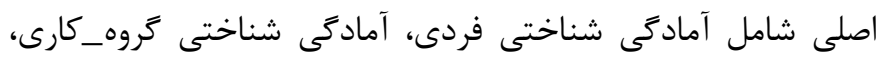

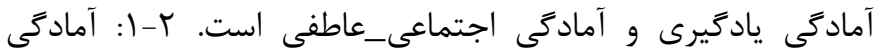
شناختى فردى: آمادگى شناختى فردى ناظر بر توانايى فردى رؤساى

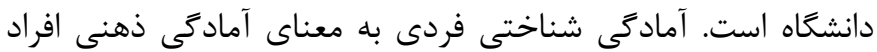

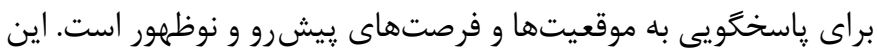

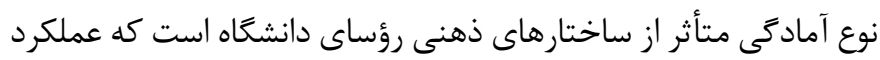

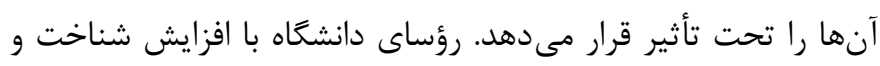

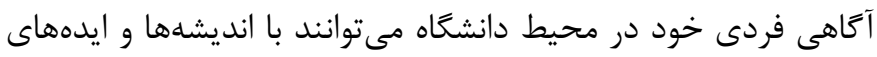

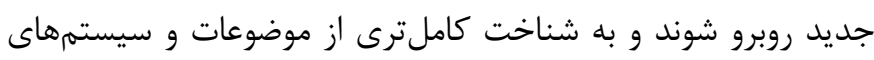

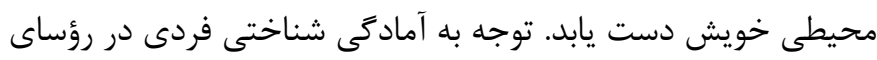

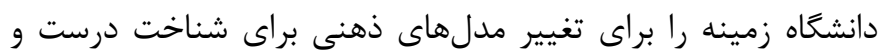
هوشمندانه محيط فراهم مىكند. ץ-ז: آمادكى شناختى گروه_كارى:

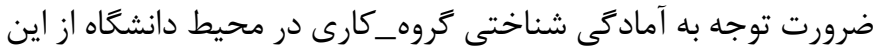

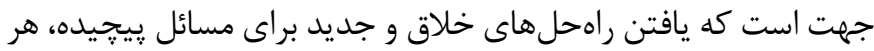
روز دشوارتر مىشود و افراد و بخشهاى سازمانها، ديخر به تنهايى قادر

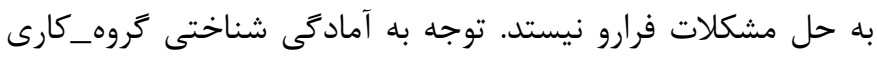

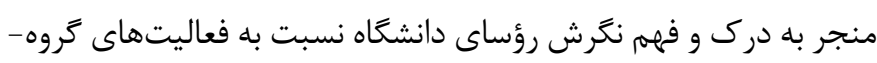

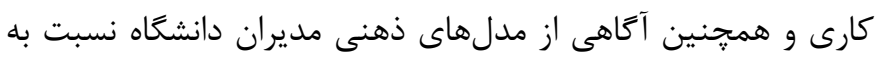
فعاليتهاى كروه_كارى مىشود و اينكه مديران دانشكاه تا جه اندازه إنهاه به مؤثر بودن فعاليتهاى گروه_كار در محيط دانشكاه باور دارند. ؟-؟ّ: با توجه به تغيير و تحولات و تأثيريذيرى دانشخاه از آنها، سازمان

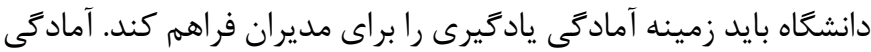

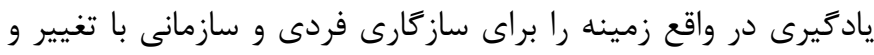

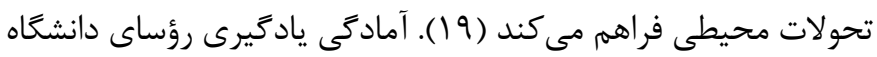

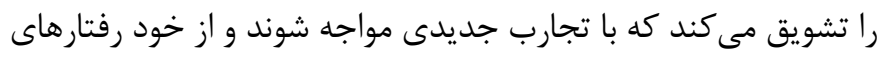

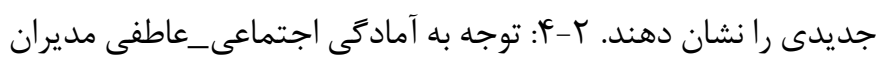

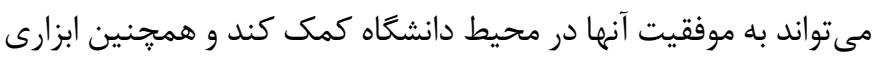




\section{References}

1. Noorshahi N. Criteria for selection and appointment of university presidents: Comparing the experiences of some universities in the world. In Yameni Dozi sokhabi M, editor. New approaches and perspectives on higher education. Tehran:Publications of the Institute for Cultural and Social Studies;2011. pp. 177-209. (Persian)

2. Hanna G. Leadership: The linchpin of effective institutional partnerships. International Journal of Higher Education Management. 2017;3(2):60-73.

3. Middlehurst R. Leadership and management in higher education: A research perspective. In Maastricht School of Management's research seminar on Leadership and Management in Higher Education, held in Maastricht. https://www. msm. nl/ resources/uploads/2014/02/MSM-WP2012-47. pdf 2012 Nov. 4. MirSepashi, N. Strategic management psychology: Theoretical challenges in strategic decision making. Journal of Tadbir. 2009;19(211):16-23. (Persian)

5. Nobre FS, Tobias AM, Walker DS. A new contingency view of the organization: mananging complexity and uncertainty through cognition. BAR-Brazilian Administration Review. 2010;7(4):379-396.

6. Binesh M.Organic metaphors. Journal of Tadbir. 2009;20(213):71-67. (Persian)

7. Grier RA. Military cognitive readiness at the operational and strategic levels: A theoretical model for measurement development. Journal of Cognitive Engineering and Decision Making. 2012;6(4):358-392.

8. Maddox EN, Forte M, Boozer RW. Learning readiness: An underappreciated yet vital dimension in experiential learning. Developments in Business Simulation and Experiential Learning. 2000;27(2000):272-278.

9. Farasatkhah M. University and higher education: Global perspectives and Iranian problems. Tehran:Ney Press;2010. (Persian) 10. Farasatkhah M. Occasionally and occasionally university in Iran: New and critical debates on university studies, science studies and higher education. Tehran:Agah Press;2017. (Persian)
11. Yamani Douzi Sorkhabi M. The new approaches and perspectives in higher education. Tehran:Research Center for Cultural and Social Studies;2009. (Persian)

12. Yamani Douzi Sorkhabi M. Planning for academic development: Theories and experiences. Tehran:Shahid Beheshti University Press;2011. (Persian)

13. Walker AD, Horn ZN, Knott CC. Cognitive readiness: The need for a multi-modal measurement approach. Proceedings of the Human Factors and Ergonomics Society Annual Meeting. 2012;56(1):443-447.

14. Baker EL. Learning and assessment: Twenty-First century skills and cognitive readiness. In: Harold F. O’Neil H, Perez R, Baker E, editors. Teaching and measuring cognitive readiness. Boston:Springer Publishing Company;2014. pp. 53-57

15. Fiore SM, Rosen MA, Pavlas D, Jentsch F. Conceptualizing cognition at multiple levels in support of training team cognitive readiness. Proceedings of the Human Factors and Ergonomics Society. 2012;56(1):448-452.

16. Supreme Council for Cultural Revolution. Strategic Plan for the development of cognitive science and technologies. Tehran:Publications of the Supreme Council for Cultural Revolution;2011. (Persian)

17. Sandelowski M, Barroso J. Handbook for synthesizing qualitative research. New York:Springer Publishing Company;2007. 18. Bazargan A. Introduction to qualitative and mixed research method, Tehran:Didar Press;2010. (Persian)

19. Mir Kamali M, Farhadi Rad H. Developing a model for assessment of organizational adaptation of university with external environment (Study of Tehran Public Universities). Journal of Educational Sciences, Shahid Chamran University. 2013;19(2):23-44. (Persian)

20. Mgbere C. Enhancing cognitive readiness: Instruction and assessment. 12th International Scientific and Technical Conference on Computer Sciences and Information Technologies (CSIT). 2017 September 5; Yerevan, Armenia; IEEE;2017.

21. Bolstad CA, Endsley MR, Cuevas HM. A theoretically based approach to cognitive readiness and situation awareness assess- 
ment. In O'Neil H, Perez R, Baker E, editors. Teaching and measuring cognitive readiness. Boston:Springer;2014. pp. 161-177.

22. Talkhabi M, Bagheri Noaparast K, Bozorgi A, Sahafi L, Mohammadi A. The coherence between cognition and emotion in education. Advances in Cognitive Sciences. 2016;18(3):68-
79. (Persian)

23. Shaemii A, Allameh SM, Askari M. Talent management strategy and its relationship with employees' emotional intelligence. Management Studies in Development and Evolution . 2013;22(70):45-75. (Persian) 